\title{
Instrument to measurement the effect of entrepreneurial orientation and innovation capability on SMEs
}

\section{Instrumento para medir el efecto de la orientación empresarial y la capacidad de innovación en MyPYMES}

\author{
PEÑA-MONTES DE OCA, Adriana Isela †* \& LÓPEZ-LAGUNA, Ana Bertha \\ Universidad Tecnológica de Jalisco, Academic Body: Social Responsibility, Sustainability and Integral Development for \\ SMEs, Mexico.
}

ID $1^{\text {st }}$ Author: Adriana Isela, Peña-Montes de Oca / ORC ID: 0001-8220-3108, CVU CONACYT ID: 70757

ID $1^{\text {st }}$ Coauthor: Ana Bertha, López-Laguna / ORC ID: 0000-0002-8145-7955, CVU CONACYT ID: 847437

DOI: $10.35429 / \mathrm{JBAB} \cdot 2020.6 .4 .16 .22$

Received January 15, 2020; Accepted June 30, 2020

\begin{abstract}
The purpose of this work is to identify, based on the literature, some of the dimensions and/or factors of the existing process in entrepreneurial ecosystems, considering the interior, financial structure, strategic alliances and decision making by senior management y the Universities through the literature review to propose a measurement instrument conductive to an entrepreneurial orientation (OE), developing its operationalization at a conceptual level to enhance innovation and improve business performance. The paper is a review of the literature published in various sources, including Journal of business Research, Human Resource Development Review, Journal of Management Studies, journal of Marketing Communications, Academy of Management Journal, International Journal of Technology Management \& Sustainable Development, among others. The results of the literary review of 137 articles allow us to recognize that: $\mathrm{OE}$ is defined by many scholars on the subject, according to different thematic approaches; the proposal by Lumpkin and Dess (1996) includes five dimensions: 1) autonomy 2) competitiveness 3) innovation 4) proactivity 5) risk taking; influenced by communication networks within strategic alliances, baked by senior management teams, their cultural profile and social responsibility, for a transdisciplinary and multidisciplinary effect that generates innovation. The results of the review allowed the construction of an instrument with a hundred questions to improve the process of measuring the impact of OE an CI on SMEs.
\end{abstract}

Entrepreneurial Orientation, Innovation, Innovation capabilities

\begin{abstract}
Resumen
El propósito del presente trabajo es identificar con base en la literatura, algunas de las dimensiones y/o factores del proceso existente en ecosistemas emprendedores, considerando al interior, estructura financiera, alianzas estratégicas y la toma de decisiones por la alta dirección y las Universidades a través la revisión de literatura para proponer un instrumento de medición conducentes a una orientación emprendedora (OE), desarrollando a nivel conceptual su operacionalización para potenciar la innovación y el mejoramiento de los rendimientos empresariales. El trabajo es una revisión de la literatura publicada en diversas fuentes, entre ellas Journal of Business Research, Human Resource Development Review, Journal of Management Studies, Journal of Marketing Communications, Academy of Management Journal, International Journal of Technology Management \& Sustainable Development, entre otros. Los resultados de la revisión literaria de 137 artículos, permiten reconocer que: la $\mathrm{OE}$ está definida por muchos estudiosos del tema, según diferentes enfoques temáticos; se distingue la propuesta por Lumpkin y Dess (1996) incluye 5 dimensiones: 1) autonomía 2) competitividad 3) innovación 4) proactividad 5) toma de riesgos; influidas por las redes de comunicación al interior de alianzas estratégicas, avaladas por el equipos de alta gerencia, su perfil cultural y la responsabilidad social, para un efecto transdisciplinar y multidisciplinar que genere innovación. Los resultados de la revisión permitieron la construcción de un instrumento con cien preguntas para mejorar el proceso de medición del impacto de la $\mathrm{OE}$ y $\mathrm{CI}$ en las MyPyMES.
\end{abstract}

Orientación emprendedora, Innovación, Capacidades de innovación

Citation: PEÑA-MONTES DE OCA, Adriana Isela \& LÓPEZ-LAGUNA, Ana Bertha. Instrument to measurement the effect of entrepreneurial orientation and innovation capability on SMEs. Journal-Business Administration-Marketing; Accounting. 2020. 4-6:16-22.

\footnotetext{
* Correspondence to Author (Email: adriana-isela@utj.edu.mx)

$\uparrow$ Researcher contributing first author.
} 


\section{Introduction}

In recent decades, studies show a tendency to reveal the impulses that allow to transform resources with creativity mediating learning capacities, adaptation capacities, absorption capacities and innovation capacities to develop a superior value and translate them into innovation (Teece, 2016). This theoretical current is known as Dynamic Capacities (CD).

In addition, the literature converges on the fact that the personality traits of entrepreneurs affect business performance (Gadner, 1983, 2001; Goleman, 1995; Krause et al., 2012), thus, promoting the development of skills such as assertiveness, tolerance, resilience, motivation, negotiation, decision-making, through the increase of collaboration networks, allows raising both internal and external knowledge, which, when articulated, impact the development of ideas, processes and products, accelerating growth and productivity (Zahra, Newey and Li, 2014; Andreeva and Ritala, 2016, Guesalaga et al., 2018; Cui et al., 2018), while strengthening businesses for their internationalization (Brown et al., 2014).

OE has a great impact on DC development, which also includes an active management process; Perhaps incorporating social clubs within the company, to support the articulation of elements such as leadership, quality human capital, while sharing ideas, work experiences in large firms, promoting business enrichment (Isenberg, 2011b).

Thus, an improvement in the results of the organization is explained by the company's ability to constantly renew itself, by identifying and exploiting new opportunities, in response to customer demands and continuous improvement.

In the context of the growth of organizations, entrepreneurship is identified among the capacities of greatest interest, since it is a factor that leads to the development of innovation capacities and the achievement of sustainable competitive advantages (Porter and Kramer, 2011; Barney, Ketchen and Wright, 2011; Marvek, Davis and Sproul, 2016).
The relationship between the entrepreneurial orientation (EO) of the company and its performance has been much studied, some in favor (Lumpkin and Dess, 1996; Wiklund and Shepherd, 2005; Lisboa, Skarmeas and Saridakis, 2016) others against (Bartholdy and Mateus, 2006; Smart and Conant, 2011), other authors argue that EO is not appropriate for all settings; and there are those who have worked OE with small companies, given their flexible organizational structure and their management with fewer barriers (Jiménez, Nieto and Castro, 2011; Arzubiaga, Iturralde and Maseda, 2012; Robinson and Stubberaud, 2014); However, the need for holistic interventions has emerged, calling for broadening the field of knowledge and breaking paradigms (Warwick, 2013: Wales, 2015). Therefore, it can be considered that the discussion is still open.

The objective of this work is to develop a new analysis proposal to measure the effect of entrepreneurial orientation and the capacity for innovation due to the influence of communication networks within strategic alliances supported by a cultural profile, focused on the creation of value. and innovation. An evaluation instrument considering various theoretical proposals to contribute in the field of knowledge at the theoretical level of the OE in relation to other disciplines. The importance of this research is based on the fact that there are no instruments in Spanish, according to the author's knowledge, that evaluate the traits and interactions, awakened through the literature and due to their importance in the economic development of the country; in order to achieve the correct fit between the environment and the capabilities that organizations must adopt to promote entrepreneurial behavior, in such a way as to promote business innovation, by generating competitive advantages in SMEs.

The second section of the work presents the conceptual framework, as well as a review of the literature and empirical studies related to $\mathrm{OE}$. The third section describes the methodology used, while the analysis and results are presented in the fourth section, to finally present and discuss the conclusions, limitations and implications for future research. 


\section{Theoretical framework}

Many are the antecedents that are identified in the literature as ideas and determining factors that, under conditions of opportunity, use knowledge, as well as their interactions and generate better production processes, better products or services, better forms of organization.

In Mexico, the Mexican industry has not been studied in depth, so it is interesting to start from internal information and knowledge processes; associate it with the existing knowledge in the environment and consider the knowledge generated in the interaction.

Miller (1983) devised a construct called Entrepreneurial Orientation (EO), the concept refers to the processes, practices and activities of decision-making for the construction of strategies and daring actions in relation to risks, which promote change, in pro of innovation, in order to generate competitive advantage (Lumpkin and Dess, 1996; George and Marino, 2011).

\section{OE dimensions and relationships.}

The extensive and growing literature has examined the importance of EO by suggesting different operationalizations of the concept, although there is no generally accepted theory. There are two main conceptualizations of the construct, unidimensional by Miller (1983) defining it in three main dimensions: 1) innovation, 2) proactivity and 3 ) risk propensity and multidimensional by Lumpkin and Dress (1996) includes 5 dimensions: 1) autonomy 2) competitiveness 3 ) innovation 4) proactivity 5) risk taking. Later studies define $\mathrm{OE}$ from a constructrivist perspective (Anderson et al., 2014) and Lisboa, Skarmeas and Saridakis (2016) analyze the three original dimensions of OE: innovation, risk taking and proactivity, as well as their interactions, with the in order to identify the circumstances that facilitate product development and productivity advantages. Bouncken, Pluschke, Pesch and Kraus (2014), investigated how EO affects within an alliance in reference to the absorption of knowledge between alliance partners in an innovation process.
These circumstances evoke the interactive nature of companies, a conducive culture, resources, policies, leadership, suppliers, customers, economy and finance, quality human capital, markets, etc. thus becoming a business system (Isenberg, 2011a)

It is important to emphasize the articulation of education, science and technological development, thus, Universities promote in their students the entrepreneurial spirit for the development of companies, with new ideas that increase the intellectual capacity of the community (Feld, 2012).

Micro and small enterprises, although they have similar characteristics, also have differences.In Mexico, INEGI classifies SMEs in manufacturing and trade sectors as: micro (up to 10 workers), small (up to 50 workers), medium (up to 250 workers), large (more than 250 workers). According to the National Survey on Productivity and competitiveness of Micro, Small and Medium Enterprises (2019), in Mexico there are just over four million SMEs, highlighting: the micro 97.6 percent of the total followed by 2 percent of small and the medians represent only 0.4 percent.

The SMEs that are in hostile environments have consistently and creatively developed new processes, products or services, increasing their competitiveness, allowing them to compete in international circuits. However, in most studies it has been observed that small companies have strong difficulties to generate sustained profitability, increase or develop business opportunities and transform them into sales (Andreeva and Ritala, 2016; Teece, 2016; Guesala et al., 2018).

In the last decade, innovative activities are displacing aspects of strategic behavior of companies, innovative activities should be understood as those that lead to the development or introduction of technological innovations, which can be classified as:

- $\quad$ Research and technological development (R\&D).

- Industrial design.

- Industrial engineering and equipment.

New products. 
- $\quad$ Marketing of new products.

- $\quad$ Technology acquisition.

- $\quad$ Technology content services.

In previous works Peña (2017), found that the variable Adoption of New Product Processes for his Company but existing in the Sector, accompanied by New forms of organization, have the greatest discriminating potential to promote innovation in SMEs

Mexico is attractive for foreign investment, due to its workforce, its geographical location and it has opted for the formation of technological capabilities based on foreign trade and the entry of foreign capital (Solleiro-Rebolledo and Castañón-Ibarrra, 2014); It currently has a favorable outlook in terms of innovation according to the Global Competitiveness Index 2018, of the world Economic forum, ranking 50th out of 140 countries in terms of innovative capacity to generate new goods and services.

There are numerous works that relate an entrepreneurial approach to raising the organizational structure, increasing its market share, better sales and profits (Wright, 2011; Anderson et al., 2014; Wilden, Devinney and Dowling, 2016).

In the literature, it was identified that the entrepreneurial company is one that is willing to take on high-risk projects under conditions of uncertainty; dependent on technological advances, technology transfer in order to be exploited and market opportunities.

\section{Methodology}

Methodology The research refers to the theoretical support, it is of a transversal type, in which the main factors of the processes in SMEs were identified, as well as the relationships between the entrepreneurial orientation and the capacity for innovation, to develop at a conceptual level an Instrument to measure the effect of business orientation and innovation capacity in SMEs, therefore the design used is non-experimental, quantitative, cross-sectional and correlational (Hernández, Fernández \& Baptista, 2010).
The scope of the research is exploratory in nature, as it approaches the problem of relatively unknown studies and, in turn, verifiable statements are suggested in order to generate knowledge that allows contributing to research on the subject.

For research strategy, we searched for articles that in their title, abstract or keywords found words such as: "Entrepreneurial Orientation", "Entrpreneurial Ecosystems", "Entrepreneurial Orientation on SME" "Entrepreneurial abilities", "cooperative alliances" " adaptive capability "، interorganizational relationships ";" Innovation "in English given that it is the most influential language among academics around the world, it is important to note that only indexed journals were included, because it is the most important form of classification in scientific journals from the academic community; the foregoing with the interest of analyzing the most recent articles by different leading researchers on the subject, in the national and international environment. In addition, for purposes of monitoring the investigation process, an Excel sheet was created to record key aspects related to the objective of the investigation. In the specific case, it was the name of the author (s), year of publication, research objective, perspective, theoretical framework, method, data retrieval instruments, data analysis, as well as main findings.

\section{Indicators}

There are innumerable number of variables that affect the concept of entrepreneurial orientation, three problems are faced:

1st. Because it is an incessant process, collecting relevant data becomes difficult.

2nd. The methods used to measure entrepreneurial orientation and capacity for innovation are very diverse and indirect.

3rd. The business heterogeneity itself makes it difficult to establish patterns that accurately reflect a factor. 
It is proposed to apply an exploratory level through a multidimensional operationalization, in three factors added to the proposal of Lumpkin and Dess (1996); communication networks within strategic alliances supported by a cultural profile, which offer a framework with human meaning and quality empowerment; competitive advantage and performance, focused on creating value and innovation. (Wolfe and Shepherd, 2013; Teece 2010).

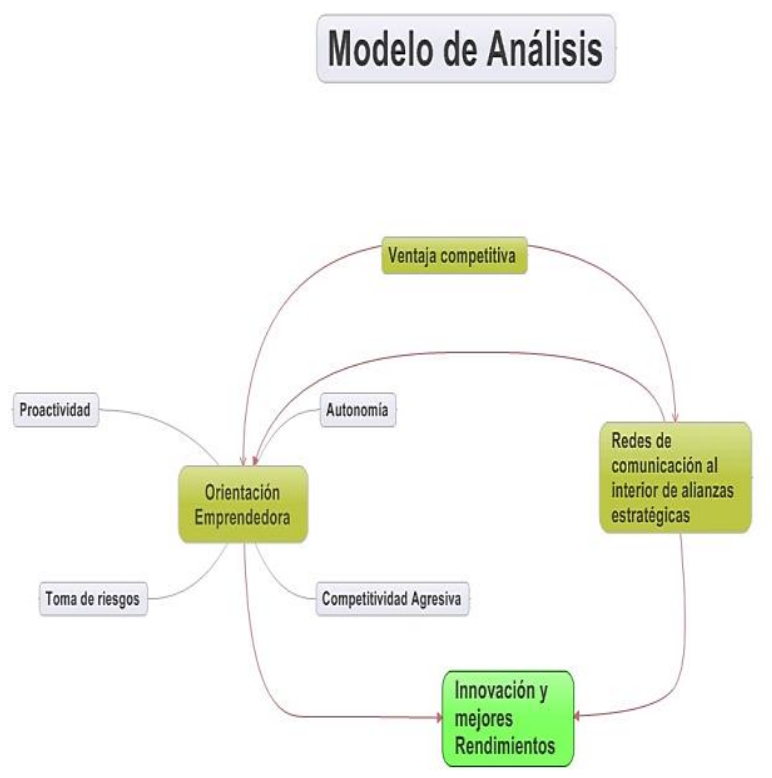

Figure 1 Explanatory model of the OE-CI relationship in MSMEs

\section{Results}

Using databases, a search for publications in scientific journals in full version was carried out in the first order through the use of keywords, to discriminate based on 178 articles for full reading

\begin{tabular}{|l|r|r|r|}
\hline $\begin{array}{l}\text { Search criteria and } \\
\text { restrictions oriented } \\
\text { to EO (English } \\
\text { terms) }\end{array}$ & $\begin{array}{c}\text { Google } \\
\text { Scholar }\end{array}$ & EBSCO & Scielo \\
\hline $\begin{array}{l}\text { Communication } \\
\text { Networks \& strategic } \\
\text { alliance }\end{array}$ & 19200 & 18 & 0 \\
\hline Alliances & 58200 & 7 & 56 \\
\hline $\begin{array}{l}\text { Definition, dimensions } \\
\text { and competitive } \\
\text { advantage }\end{array}$ & 506000 & 43 & 87 \\
\hline Measurement & 260000 & 1 & 1 \\
\hline Autonomy & 21800 & 9 & 4 \\
\hline Innovation & 556000 & 5 & 22 \\
\hline Proactivity & 31000 & 43 & 3 \\
\hline Take risks & 441000 & 2 & 13 \\
\hline $\begin{array}{l}\text { Aggressive } \\
\text { competitiveness }\end{array}$ & 26900 & 859 & 7 \\
\hline
\end{tabular}

Table 1 Analysis in databases
According to the literature reviewed, it was observed that there are more studies that have used three-dimensional scales than five, the measurement instruments range in the number of items from 7 to 100 and it is observed that in any attempt to measure the OE faces: 1) subjectivity as a function of appreciation ability, influenced by predictions and expectations, as a consequence of change in favor of continuous improvement. 2) indirect measurement and 3) heterogeneity.

In the case of SMEs, due to their specific characteristics, they tend to establish less formal controls. For all these reasons, it is considered appropriate to consider communication networks within strategic alliances supported by a cultural profile, given that they offer a framework with a human sense and quality empowerment, focused on the creation of value and innovation.

Link 1 shows the questionnaire consisting of 7 subdomains and a total of 100 items, to be tested and distributed through the web. The structure of the instrument includes: 1) Presentation, 2) Data of the interviewee, 3) Data and characteristics of the company, 4) Risks and Decision-making, 5) Proactivity, learning and innovation, 6) Resources and skills, 7) Orientation Entrepreneur; It is measured from items in question form, on a 5-point Likert scale: $1=$ Strongly disagree $2=$ Disagree $3=$ Neither agree nor disagree $4=$ Agree $5=$ Totally agree, which can be self-rated.

\section{Link 1}

https://docs.google.com/forms/d/1qvZQmrBnO bv2v1TyDYnlPR9_2ckI4HE2xo4BIsciLvo/edit

\section{Conclusions}

The study shows seven subdomains that can be interrelated in SMEs; three factors added to the proposal of Lumpkin and Dess (1996); communication networks within strategic alliances supported by a cultural profile, competitive advantage and performance, focused on creating value and innovation. 
Recognizing that innovation projects are composed of more than one source of knowledge, type of organization, geographical location, sector and market niche; thus, in the dynamics of innovation, organization, technologies, sector dynamics and the response of society are interwoven (Rip, 2012).

The present study is not without its limitations, the complete coverage of all the articles dealing with OE and / or IC could not have been achieved, given the search procedure chosen. Therefore, there could have been works that, having been directed to OE and / or CI, a different language was used. Consequently, the factors derived from the analysis need to be treated with caution.

\section{References}

Anderson E.S., Kreiser P.M. Kuratko, D.F. Hornsby J.S., Eshima Y. (2014). Reconceptualizing entrepreneurial orientation. Strategic Management Journal 36: 1579-1596.

Andreeva, T., y Ritala, P. (2016). What are the sources of capability dynamism? Reconceptualizing dynamic capabilities from the perspective of organizational change. Baltic Journal of Management, 11 (3), 238-259.

Arzubiaga, U., Iturralde, T. y Maseda, A. (2012). La medición de la Orientación Emprendedora en las empresas familiares: Una revisión crítica de la literatura. Revista de Empresa Familiar, 2, 5771.

Bartholdy, J., y Mateus, C. (2006). Debt and Taxes: Evidence from bank-financed unlisted firms. Aarhus School of Business, Finance Research Group, Working paper F-2006, 2.

Barney, J.B., Ketchen, D.J., y Wright, M., (2011). The Future of Resource-Based Theory: Revitalization or Decline? Jounal of Management, 37 (5), 1299-1315.

Bouncken, R.B., Pluschke, B.D., Pesch, R., y Kraus, S., (2014) Enrepreneurial orientation in vertical alliances: Joint product innovation and learning from allies. Review of Managerial Science, 10 (2) 1-29, 381-409.
Brown, R. y Mawson, S- (2014) The Geography of Growth in High Growth firms: The Implications of 'Growing Abroad', School of Management Working Paper, University of St. Andrews.

Cui, L., Fan, D., Guo, F., y Fan, Y., (2018) Explicating the relationship of entrepreneurial orientation and firm performance Underlying mechanisms in the context of an emerging market, Industrial Marketing Management, 71, 27-40.

Feld, B. (2012) Startup Communities: building on entrepreneurial ecosystem in your city, Hoboken: NJ, Wiley.

Gadner, H. (2001). La inteligencia reformulada. Las inteligencias múltiples en el siglo XXI. Madrid: Editorial Paidós

George, B. A., y Marino, L. (2011). The epistemology of entrepreneurial orientation: Conceptual formation, modeling and operationalization. Entrepreneurship Theory and Practice, 35 (5). 989 - 1024.

Goleman. D. (1996). Inteligencia emocional. Barcelona: Editorial Kairós.

Guesalaga, R., Gabrielsson, M., Rogers, B., Ryals, L., y Marcos Cuevas, J., (2018). Which resources and capabilities underpin strategic key account management? Industrial Marketing Management, 75, 160-172.

Isenberg, D. (2011a) The entrepreneurship ecosystem strategy as a new paradigm for economy policy: principles for cultivating entrepreneurship, Babson Entrepreneurship Ecosystem Project, Babson College, Babson Park: MA.

Isenberg, D. (2011b) When big companies fall, entrepreneurship rises, Harvard Business Review.

Jiménez, J.C., Nieto, M. de L., y Castro, R. (2011). Artesanía influencia de la orientación emprendedora en el desempeño de las empresas de artesanía. Congreso Internacional de Contaduría, Administración e Informática de la Universidad Nacional Autónoma de México, México, D.F. 
Kraus, M. W., Piff, P. K., Mendoza-Denton, R., Rheinschmidt, M. L., \&Keltner, D. (2012). Social class, solipsism, and contextualism: How the rich are different from the poor.

Lisboa, a., Skarmeas, D., y Saridakis, S. (2016). Entrepreneurial orientation pathway to performance: A fuzzy-set analysis. Journal of Business Research, 69 (4), 1319-1324.

Lumpkin, G.T. y Dess, G.G. (1996). Clarifying the entrepreneurial orientation construct and linking it to performance. Academy of Management Review, 21 (1), 135-172.

Marvel, M.R,, Davis, J.L. and Sproul, C.R. (2016). Entrepreneurial orientation, marketing capabilities and performance. The Moderating role of Competitive Intensity on Latin America International New Ventures. Journal of Business Research, 69 (6), 2040-2051.

Peña-Montes de Oca, A. (2017) Deducción de factores principales que favorecen innovación, en procesos de transferencia de tecnología entre EMN y PyMES de Tecnologías de Información en Sonora México. QUID (29) 60-65.

Porter, M. E., y Kramer, M.R. (2011) Creating shared value. Harvard Business Review, (February), 63-77.

Rip A. (2012) The Context of Innovation Journeys, Creativity and Innovation. Journeys Vol. 21 (2), 158-170.

Robinson, S., y Stubberud, H.A., (2014) Elements of entrepreneurial orientation and their relationship to entrepreneurial intent. Journal o Entrepreneurship Education, 17 (2), 1-12.

Smart, D. T., y Conant, J.S. (2011). Entrepreneurial orientation, distinctive marketing competencies and organizational performance. Journal of Applied Business Research (JABR), 10 (3), 28-38.

Solleiro J.L., Gaona C., Castañón R. (2014) Políticas para el desarrollo de Sistemas de Innovación en México. Journal of Technology Management \& Innovation Vol. 9 (4)

Teece, D.J. (2016) Dynamic capabilities and entrepreneurial management in large organizations: Toward a theory of the (entrepreneurial) firm. European Economic Review, 86, 202-216.
Wales, W.J. (2015). Entrepreneurial orientation: A review and synthesis of promising research directions. International Small Business Journal, 1-13.

Warwick, K (2013) Beyond Industrial Policy: emerging issues and new trends, OECD Science, Technology and Industry Policy Papers, No. 2. OECD.

Wiklund, J. y Shepherd, D. (2005). Entrepreneurial Orientation: Performance Relationship, Entrepreneurship Theory and Practice, 24, 37-48.

Zahra, S. A., Newey, L. R., y Li, Y. (2014). On the Frontiers: The Implications of Social Entrepreneurship for International Entrepreneurship. Entrepreneurship Theory and Practice, 38 (1), 137-158. 